\title{
COVID-19 and the governmentality of emergency food in the City of Turin
}

\author{
Massimo Sargiacomo \\ Management and Business Administration, \\ University G.d'Annunzio of Chieti-Pescara, Pescara, Italy \\ Laura Corazza \\ Department of Management, University of Turin, \\ Turin, Italy \\ Antonio D'Andreamatteo \\ Management and Business Administration, \\ University G.d'Annunzio of Chieti-Pescara, Pescara, Italy \\ John Dumay \\ Department of Accounting and Corporate Governance, Macquarie University, \\ Sydney, Australia and \\ Department of Management, University of Bologna, \\ Bologna, Italy, and \\ James Guthrie \\ Department of Accounting and Corporate Governance, Macquarie University, \\ Sydney, Australia and \\ Knowledge Research Pty Ltd, New South Wales, Australia
}

\begin{abstract}
Purpose - This paper shows the accounting, accountability and calculative practices associated with emergency food allocations by the City of Turin through a program to feed the vulnerable during COVID-19. Design/methodology/approach - This is a single case study framed by Foucault's governmentality concept. The data was collected through interviews with key institutional actors and triangulated against decrees, circulars, ordinances and other publicly available documents.

Findings - The accounting tools of governmentality are always incomplete. Sometimes unique situations and crises help us to revise and improve the tools we have. Other times, they demand entirely new tools.

Research limitations/implications - Accounting needs both things to count and a context to count them. In the case of food assistance, what is counted is people. In Turin's case, many people had never been counted either because there was no need or because they were unaccounted for by choice. Now, the government was accountable for the welfare of both. Thus, new classification systems emerged, as did organisational and accounting solutions.
\end{abstract}

(C) Massimo Sargiacomo, Laura Corazza, Antonio D’Andreamatteo, John Dumay and James Guthrie. Published by Emerald Publishing Limited. This article is published under the Creative Commons Attribution (CCBY 4.0) licence. Anyone may reproduce, distribute, translate and create derivative works of this article (for both commercial and non-commercial purposes), subject to full attribution to the original publication and authors. The full terms of this licence may be seen at http://creativecommons. org/licences/by/4.0/legalcode

The authors are grateful for the constructive comments received from the two anonymous reviewers, and from the guest editors. The authors especially thank the interviewees for their time and candid insights. A special thank goes to the Department of Social Policy of the City of Turin and to the ViceMayor of the City of Turin, without which this paper would not have been possible.

COVID-19 and the emergency food

Received 14 September 2020 Revised 19 December 2020 24 February 2021 Accepted 5 April 2021 
Originality/value - Although the accounting-for-disasters literature is diverse, studies too often favour the macro social, economic and political issues surrounding crises, neglecting the micro issues associated with governmentality and calculative practices.

Keywords COVID-19, Governmentality, Food, Vulnerable population, Accounting, Calculations, Turin Italy Paper type Research paper

\section{8}

\section{Disasters, food, government and accounting}

Families with babies, families where both wife and husband worked with an undeclared contract, like the Philippines community or the Peruvian community, all of them have lost their job because they work as domestic workers and carers [1].

This paper explores governmental accounting, accountability and calculative practices through an emergency food assistance program operating in Turin, Italy, during the COVID-19 pandemic in early 2020. Drawing on interviews and publicly-available documents, we interpret the data using Foucault's concept of governmentality, which is "a certain way of thinking and acting embodied in all those attempts to know and govern the wealth, health and happiness of populations" (Rose and Miller, 1992, p. 174). The period of study spans 31 January-31 July 2020. During this time, the Italian federal government, the regional government of Piedmont, and the City of Turin implemented governmentality systems to manage emergency food assistance programs.

The intersection between accounting and calculative practices in crises is of continuing interest to accounting researchers. From bushfires (Taylor et al., 2014), droughts (Walker, 2014), floods (Lai et al., 2014; Sciulli, 2018), earthquakes (Sargiacomo et al., 2014; Sargiacomo, 2015) and hurricanes (Baker, 2014; Perkiss and Moerman, 2020), the accounting-for-crises literature is varied. However, while these studies contribute to our understanding of the macro social, economic and political issues surrounding crises, they are often silent on the micro issues (see Perkiss and Moerman, 2020, p. 11). Additionally, except for studies on issues concerning the HIV pandemic in Africa (Rahaman et al., 2010), there is still much to learn about the intersection between accounting and calculative practices in crises triggered by major public health emergencies, which are becoming more frequent $(\mathrm{Yu}, 2021)$.

We explore emergency food distribution in a crisis as part of the ongoing interrelations between accounting, food, state, local authorities and social institutions with a specific focus on how these institutions are involved in the political economy and the regulation, allocation and distribution of food to people (Sargiacomo et al., 2016). Attention has been to investigating food allocation pipelines (e.g. MacRae and Abergel, 2012) from an accountability perspective ever since Dodd's (1856) The Food of London. However, this interest has not extended as far as accounting research into disaster and crises to date. The COVID-19 pandemic provides a contemporary context for putting the accounting and calculative practices associated with emergency food assistance under the microscope. More specifically, it is an opportunity to investigate how governmentality practices develop to ensure food reaches those in need during a crisis.

Governmentality studies are a way to investigate accounting and calculative practices. For example, Sargiacomo (2015) draws on the main principles of Foucault's (1991) "art of government" to underpin his study of managing the aftermath of Italy's 2009 earthquake. He highlights that governmentality studies are useful because they "emphasise how accounting helps to facilitate normal governance, [ . . when] things do not always proceed according to plan" and, more pointedly, that "unexpected events require departures from the'normal"' (p. 84).

First, we reveal the relationship between accounting, calculative practices, accountability and disasters by unveiling how local, regional and national government 
work in tandem with social institutions. Second, we contribute to the governmentality literature with a case on the intersections between accounting and emergency food assistance to city populations during a pandemic. Thus, our case study contributes to an understanding of how governance and accounting practices during a crisis might help save people's lives.

\section{Methods}

COVID-19 and the emergency food

Before COVID-19, one of the authors was already working on a research project into how charities assist the poor. This research meant we had already undertaken interviews and collected some documents about food assistance, NGOs and Turin's distribution processes. Before COVID-19, national, regional and local government laws prescribed the rules for distributing food activities and roles. This prior research enabled us to identify critical institutional and individual actors to inform our research immediately after Italy declared a State of emergency in January 2020. We analysed over 40 documents, including national, regional and local government decrees, debates, circulars and ordinances - plus more than $20 \mathrm{~h}$ of video footage of Turin City Council meetings and local committees. Figure 1 illustrates the period of analysis beginning 1 January 2020, through to the lockdown from 9 March to 18 May, and ending on 31 July.

Table 1 provides a list detailing the semi-structured interviews conducted before COVID and from April to June 2020. The interviewees we highlight in Table 1 provide data for identifying our meta themes that identify the apparatus and the technologies adopted for allocating food assistance activities. During the interviews, one author made written notes. In some instances, we conducted follow-up interviews with questions and written responses via telephone and email.

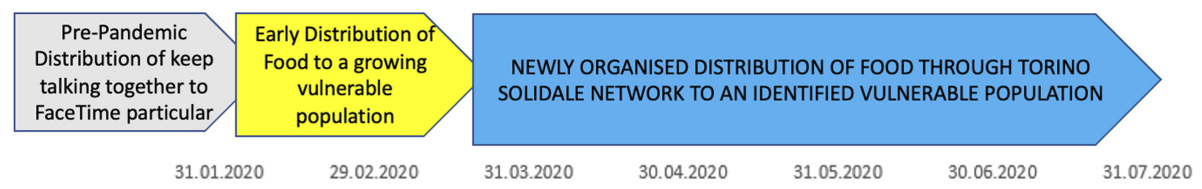

03.02.2020 OCCPD no. $630 \mathrm{CPD}$ establishes an expense chapter

25.02.2020 OCCPD no. 639 Piedmont Region establishes a special accounting system

24.03.2020 Creation of Torino Solidale Network

29.03.2020 OCCPD no.658 $€ 400 \mathrm{~m}$ decree for food solidity measure

Local government City of Turin: $€ 4,6 \mathrm{~m}$

06.04.2020-10.04.2020 Torino Solidale: distribution of food vouchers 06.04.2020 Book account Urgent measure for food solidarity in the financial statement of the City of Turin

06.04.2020 Additional $€ 663.000$ granted through LGD no. 908

23-25.05.2020 C.P.D. Circular no. 30491 and related regulation

Launch of "Reporting procedure and reimbursement of costs incurred for Assistance to the Population", including "Food".

27.05.2020 Solidarity bank account $€ 212,225.08$

15.06.2020 Piedmont Region donation and Chamber of Commerce donation $€ 250,000+$ $€ 200,000$

Figure 1.

A timeline of events or changes affecting the distribution of food in Turin 


\section{AAAJ 34,6}

1460

Table 1.

\begin{tabular}{|c|c|c|c|c|c|}
\hline & Interviewee & Day & Location & Duration & Focus \\
\hline \multirow[t]{4}{*}{$\begin{array}{l}\text { Before } \\
\text { COVID }\end{array}$} & $\begin{array}{l}\text { Director of Sermig [one } \\
\text { of the hubs during the } \\
\text { emergency] }\end{array}$ & 12.03 .2019 & Main office & $2 \mathrm{~h}$ & \multirow{4}{*}{$\begin{array}{l}\text { The management of food } \\
\text { solidarity programmes from } \\
\text { traditional welfare to social } \\
\text { innovation }\end{array}$} \\
\hline & $\begin{array}{l}\text { Director of Caritas } \\
\text { [involved during the } \\
\text { emergency in the hubs } \\
\text { work] }\end{array}$ & 02.04.2019 & Main office & $2 \mathrm{~h}$ & \\
\hline & $\begin{array}{l}\text { Director of Cottolengo } \\
\text { [one of the hubs during } \\
\text { the emergency] }\end{array}$ & 11.04.2019 & $\begin{array}{l}\text { Soup } \\
\text { kitchens for } \\
\text { the most } \\
\text { deprived }\end{array}$ & $2 \mathrm{~h}$ & \\
\hline & $\begin{array}{l}\text { Manager of Food Pride } \\
\text { Network [involved } \\
\text { during the emergency } \\
\text { in the hubs work] }\end{array}$ & 03.06.2019 & Phone call & $1 \mathrm{~h}$ & \\
\hline \multirow{5}{*}{$\begin{array}{l}\text { During } \\
\text { COVID }\end{array}$} & Regional Council & 25.05 .2020 & Virtual & $1 \mathrm{~h}$ & \multirow{3}{*}{$\begin{array}{l}\text { The management of food } \\
\text { voucher distribution from } \\
\text { governmental legislation to } \\
\text { local implementation, after } \\
\text { the state of emergency } \\
\text { declaration } \\
\text { Food hubs daily operations }\end{array}$} \\
\hline & Member & & & & \\
\hline & $\begin{array}{l}\text { Project Manager of the } \\
\text { Local Community } \\
\text { Center Casa del } \\
\text { Quartiere (one of the } \\
\text { hubs) }\end{array}$ & 17.06 .2020 & Virtual & $1 \mathrm{~h}$ & \\
\hline & $\begin{array}{l}\text { Vice-Mayor of the City } \\
\text { of Turin }\end{array}$ & 17.06 .2020 & Virtual & $1 \mathrm{~h}$ & \multirow{2}{*}{$\begin{array}{l}\text { The design of Torino Solidale } \\
\text { Network and its managemen } \\
\text { Operational profiles and } \\
\text { accountability implications }\end{array}$} \\
\hline & $\begin{array}{l}\text { Director of the Social } \\
\text { Policy Department }\end{array}$ & 18.06 .2020 & Virtual & $1 \mathrm{~h}$ & \\
\hline
\end{tabular}

From this corpus, we identified new meta-themes explicitly relating to food distribution in the pandemic. We also triangulated common elements (convergence) and discovered complementary elements (extension of the previous knowledge) (Grafton et al., 2011).

\section{Governing populations during epidemics}

Foucault (1991, p. 189) states that "for half a century after the great cholera epidemic of 1832 , Europeans were obsessed by fears of epidemic disease". In a subsequent paper, how each province "had to take care of public health, diseases, epidemics and accidents . .., and it had to manage a kind of insurance for people to be protected against all such accidents" (1994, p. 411). Later still, he explains how, historically, the challenge of governing "population was posed in relation ... to major human catastrophes" (2007, p. 67). Prior accounting studies on governmentality have already provided insights on healthcare (Sargiacomo, 2015) and evacuee-housing following an earthquake (Sargiacomo and Walker, 2021). However, researchers have yet to explore the governance of populations "after a great disaster, be it an epidemic ... or food shortage" (Foucault, 2007, p. 61).

Rose and Miller (1992, p. 175) argue that academia has a responsibility alongside the fourth and fifth estates to frame political issues and make visible how governments are exercising their power:

The problematics of government should also be analysed in terms of their governmental technologies, the complex of mundane programmes, calculations, techniques, apparatuses, 
documents and procedures through which authorities seek to embody and give effect to governmental ambitions.

Drawing on the case provided by "the town, scarcity and the epidemic" (Foucault, 2007, p. 63), and starting from the assumption that "government is the right disposition of things arranged so as to lead to a convenient end" (Foucault, 1991, p. 93), we analyse how a city government used accounting technologies, calculations and lists to allocate and distribute food to the poor and a broader group of the vulnerable during the COVID-19 pandemic.

Lists of people sit at the heart of this case - lists of the elderly, lists of the disabled, the poor and food insecure, those in strict isolation and quarantine, old lists, new lists, and people who should be on lists but are not. Homogenous social lists are a standard part of charities' calculative practices that help the poor and needy (Walker, 2004; Servalli, 2013). They are also a standard tool for supporting governmentality programs, for instance, to assist evacuees in the aftermath of natural disasters (Sargiacomo and Walker, 2021, p. 15). Bowker and Star (1999, p. 138) highlight that "when lists are used to coordinate important work that is distributed widely over time and space, a corresponding complex organisational structure and infrastructure evolves". Infrastructure may evolve during "the regulations for times of epidemic" when we observe "measures taken in plague towns, and the quarantines enforced ... all constituted forms of authoritarian medicalisation" (Foucault, 1994, p. 92).

\section{Governance, accounting and calculative practices for distributing food to the vulnerable}

4.1 The pre-COVID state in Turin

Turin is in north-eastern Italy. It is the fourth most populated Italian city with less than $1 \mathrm{~m}$ citizens and home to the fourth-largest concentration of immigrants $(15 \%)$ (Centro Einaudi, 2019). Turin has been described as "two cities in one" because $30 \%$ of its population has considerable financial means, while the other $70 \%$ fall near or below the poverty line (Centro Einaudi, 2019). Of its population, almost $25 \%$ are over 65 , and $40 \%$ have an annual income of less than $€ 15,000$, which, by law, is the average family income threshold needed to apply for essential social service relief (see Table 2).

Among these statistics used to count the vulnerable before COVID, none pertain to food distribution. Private initiatives led by NGOs largely fulfilled this function, sometimes in collaboration with the city, sometimes not.

Notably, since 2015, Turin was among the first Italian cities to sign the Milan Food Pact [2]. The pact stipulates that Mayors are responsible for providing "cash and food transfers, and other forms of social protection systems (food banks, community food kitchens, emergency food pantries)" to vulnerable people.

Consequently, the City of Turin amended one of its statutes to reflect this responsibility [3], i.e.:

To promote the implementation of the right to adequate food, as the right to have regular, permanent and free access to quality food, sufficient, nutritious, healthy, culturally and religiously acceptable, which guarantees mental and physical satisfaction, for the individual and the population, necessary to lead a worthy life.

In 2018, Turin established a Social Inclusion Plan involving 110 NGOs and associations to serve as a repository of co-designed projects and a collector of any public or private financial funds to be spent on local welfare. Initiatives to feed the poor, such as soup kitchens managed by local NGOs (13 in total in 2020).

As such, operational control of all food deliveries pre-COVID remained with the NGOs, and the City did not design its lists to track those affected by food shortages. Therefore, when the pandemic hit, new lists had to be drawn up of people who needed feeding. Some identified new
COVID-19 and the emergency food 


\begin{tabular}{|c|c|c|c|c|c|}
\hline \multirow{3}{*}{$\begin{array}{l}\text { AAAJ } \\
34,6\end{array}$} & \multicolumn{2}{|l|}{ List } & Number & Source & Date \\
\hline & Inhabitants & & 875,698 & $\begin{array}{l}\text { Popular Financial } \\
\text { Reporting }\end{array}$ & Dec 19 \\
\hline & Elderly (>70 years) & & 176,290 & $\begin{array}{l}\text { Social Inclusion } \\
\text { Plan }\end{array}$ & Nov 19 \\
\hline \multirow{2}{*}{1462} & Legal immigrants & & 123,380 & $\begin{array}{l}\text { ISTAT and } \\
\text { Rapporto Rota }\end{array}$ & Dec 18 \\
\hline & \multirow{2}{*}{ Indirectly assisted by social services } & \multicolumn{2}{|r|}{71,519} & \multirow{2}{*}{$\begin{array}{l}\text { Popular Financial } \\
\text { Reporting }\end{array}$} & \multirow[t]{2}{*}{ Dec 18} \\
\hline & & $\begin{array}{l}\text { (1) } \\
(2) \\
(3) \\
(4) \\
\\
(5)\end{array}$ & $\begin{array}{l}\text { 14,285 families with babies } \\
\text { (incl foster care) } \\
13,961 \text { disabled } \\
17,972 \text { elderly living alone } \\
13,015 \text { adults with specific } \\
\text { needs* } \\
12,789 \text { immigrants and } \\
\text { nomads }\end{array}$ & & \\
\hline & \multirow{2}{*}{$\begin{array}{l}\text { Directly assisted by social services in } \\
\text { the City of Turin in } 2018\end{array}$} & & 7,510 & \multirow{2}{*}{$\begin{array}{l}\text { Popular Financial } \\
\text { Reporting }\end{array}$} & \multirow[t]{2}{*}{ Dec 18} \\
\hline & & $\begin{array}{l}(1) \\
(2) \\
(3) \\
(4)\end{array}$ & $\begin{array}{l}1,437 \text { minors } \\
897 \text { aged }>60 \\
3,546 \text { disabled } \\
1,630 \text { immigrants }\end{array}$ & & \\
\hline & Homeless & 1,80 & 0 (estimated) & $\begin{array}{l}\text { Popular Financial } \\
\text { Reporting }\end{array}$ & Dec 18 \\
\hline & $\begin{array}{l}\text { People who receive social cards and } \\
\text { basic income }\end{array}$ & & 17,000 & $\begin{array}{l}\text { Social Inclusion } \\
\text { Plan }\end{array}$ & Dec 18 \\
\hline & Distribution of income (\%) & (1) & $€ 0(1 \%)$ & OCCPD no. 658 & Mar 20 \\
\hline & & $(2)$ & $€ 0$ to $€ 10,000(26 \%)$ & & \\
\hline & & (3) & $€ 10,000-15,000(13 \%)$ & & \\
\hline & & $\begin{array}{l}(4) \\
(5)\end{array}$ & $\begin{array}{l}€ 15,000-26,000(33 \%) \\
€ 26,000-55,000(22 \%)\end{array}$ & & \\
\hline \multirow{4}{*}{$\begin{array}{l}\text { Table } 2 \text {. } \\
\text { Lists of Turin's } \\
\text { inhabitants pre- } \\
\text { COVID-19 }\end{array}$} & & (6) & $€ 55,000-75,000(3 \%)$ & & \\
\hline & & (7) & $€ 75,000-120,000(2 \%)$ & & \\
\hline & & (8) & $>€ 120,000(1 \%)$ & & \\
\hline & \multicolumn{3}{|l|}{ Note(s): *e.g. unemployed, drug addicts } & & \\
\hline
\end{tabular}

"vulnerable populations", such as COVID-positive individuals subject to home recovery or precautionary quarantine and people who had lost their jobs. Others were lists of invisible people who needed to become visible, e.g. illegal immigrants and undocumented workers.

\subsection{Distributing emergency food assistance to a growing vulnerable population}

On 3 February 2020, the Minister of the Interior released the first ordinance to tackle the COVID-19 pandemic (OCCPD no. 630). The ordinance defined responsibilities for various government levels and established an expense chapter with the Civil Protection Department (CPD) to face COVID-19 and prevent it from spreading. A few weeks later, each region, including Piedmont, was required to create a unique COVID-19 accounting centre (OCCPD n. 639, 25 February 2020). Three days later, Turin set up a Local Government Operations Centre to help its 900,000-strong population face an imminent nationwide lockdown (which ended on 9 March 2020). The Centre managed communications, the media, and the flood of calls coming in on an emergency hotline. Food management during the emergency was placed "under the direct control of the City of Turin" (Regional Council Member, Interview). This control meant collaborating with a central Food Bank as a buyer of processed food and a collector of fresh food surplus from 
the local agri-food centres. It also involved working with the Bank of the Charity Works (Banco delle Opere di Carità) to ensure that staff could complete emergency deliveries while still complying with social distancing guidelines.

By March, only 5 of the city's 13 soup kitchens remained open due to social distancing rules and the demographics of the workers and patrons who frequent food shelters. As the Vice-Mayor of Turin explains, "Most of the volunteers working with our local associations and NGOs are retired, the most in danger during the pandemic, and this has affected the possibility of providing the same quality level of the food services" (Interview, 18 June 2020). As more retail food stores closed and the quantity of surplus food collected declined in both quality and quantity, those relying on the soup kitchens began to protest. In response, the Food Bank began to order fresh food from the local markets instead.

\subsection{The Torino Solidale network}

Toward the end of March, a local government directive formed Torino Solidale, a network of 12 emergency food and essential supply hubs throughout the city for the needy and households without local support. The City of Turin managed the network alongside thirdsector organisations chosen from those already participating in the Social Inclusion Plan. Turin's NGO network was already using some hubs to feed the poor before the pandemic, so Torino Solidale expanded from the existing infrastructure. Foucault (1988, p. 142) would describe this as an "upgrade to government technology" that required a "new mapping and the closer surveillance of the urban space". Figure 2 illustrates a map of the community centres in the most deprived areas and the logistics centres used to distribute the food to the 12 hubs.

During the state of emergency, feeding the poor turned into feeding the new poor. Thus, a larger, more diverse group of people labelled "the vulnerable", amalgamated from various purpose-built lists of citizens, each requiring their own urgent, yet tailored-made, government solution emerged. For example, one list comprised the elderly, the infected, and the quarantined, who were all subject to "authoritarian medicalisation" (Foucault, 1994, p. 92) in that they had financial resources but were not allowed to go shopping. Thus, to those on this list, CPD offered a paid food delivery service.

A second list was of those facing extreme financial difficulty, whether entrenched or for the first time. For these new poor, the city-funded a web portal where people could apply for food e-vouchers and, later, for food baskets. People could also register for assistance through a mobile app, by phone or in person. The most impoverished people were usually registered both by local government officers and a network of volunteers to ensure they received food assistance. A Torino Solidale representative interviewed each applicant before being included on the list. During the interviews, narrative accounts of their situation were a critical factor in approving the applications than other quantitative criteria.

\subsection{The fund for food solidarity}

At the same time, Turin was organising its emergency food distribution plans, and the federal government was organising theirs (OCCPD no. 658). On 29 March, just five days after Torino Solidale commenced operations, the Italian government announced $€ 400 \mathrm{~m}$ in support for the Fund for Food Solidarity to be proportionally distributed between the municipalities using financial and non-financial criteria. The CPD performed the calculations and funding allocations in keeping with the relevant bookkeeping and accounting guidelines in tandem with ANCI (the Italian association of municipalities). These calculations provided the inscriptions about how the cities would receive and spend public money to organise food assistance.

Specifically, $80 \%$ of the money was allocated based on population, with the remaining $20 \%$ based on the difference between the average resident's income and the national average. 
AAAJ

34,6

1464

Figure 2.

The map of the City of Turin reporting the territorial hubs of Torino Solidale



Source(s): Elaboration of the authors on data collected during the interviews and other secondary sources

Subsequently, "the mayors of the largest cities, [...] started working on the subsequent elaboration of an implementation guideline to help them manage distributing funds" (Regional Council Member, Interview). However, as there are no official counts of homeless people for any city, these people were not on the central government's lists and, therefore, not factored into this temporary relief program calculations.

Turin received around $€ 4.6 \mathrm{~m}$ of the total $€ 400 \mathrm{~m}$ budget and added another $€ 663,000$ of its funding to support the program's activities in the local area. The funds were apportioned as follows: $€ 4.29 \mathrm{~m}$ on food vouchers; $€ 120,000$ on prepared meals for home delivery, the 
homeless and immigrants; and $€ 880,000$ to Torino Solidale to buy and distribute food baskets. Deciding how to apportion the money was a complicated process, as was how to distribute the vouchers, meals and baskets equitably. For example, to qualify for food vouchers, applicants had to declare that they were suffering financial distress caused by the pandemic; and no-one in the family was benefitting from another public subsidy. Only one family member could request the food vouchers and the dollar amount depended on the number of people in family $(1-2=€ 300 ; 3-4=€ 400 ; \geq 5=€ 500)$. Table 3 outlines the income and expenditure of these funds from January through July.

As part of the approval process, officials cross-checked applicants against social services lists to ensure no-one received double support. But Turin decided to "not apply any criteria linked to income during the emergency, and all the controls would be performed ex-post, to guarantee an expedited action for the vulnerable people" (Turin Vice-Mayor, Interview, 18 June 2020). Also, the web portal listed 150 accredited local shops where recipients could redeem their vouchers. A cloud platform tracked where the vouchers had been redeemed, including the distance between the voucher holder's residence and the shop. This system reflects a "buyer-supplier" governmental technology that connects assisted populations to suitable local suppliers. Other items tracked were daily redemptions, family composition and the type of entitlement. The tracking provided some accountability over the funds. For example, the city constructed maps reporting voucher use concentrations across Turin's districts. As one City Councillor stated:

The portal opened in the week from 6 April to 10 April. Once the news was released, we received more than 1,000 calls per hour. On 6 April, we distributed nearly $€ 1 \mathrm{~m}, € 1.38 \mathrm{~m}$ the second day, $€ 1.2 \mathrm{~m}$ the third day and nearly $€ 0.6 \mathrm{~m}$ the fourth and fifth day, and we went rapidly over budget during the weekend. We distributed vouchers to 12,752 families in four days [...], and there was not a

\begin{tabular}{|c|c|c|c|c|}
\hline Date & $\begin{array}{l}\text { Commitment of } \\
\text { expenditure }\end{array}$ & Funding source & Income $€$ & $\begin{array}{c}\text { Expenditure } \\
€\end{array}$ \\
\hline $29 \operatorname{Mar} 20$ & & Civil Protection OCCPD no. 658 & $4,624,012.40$ & \\
\hline 02 Apr 20 & 1,063 & Purchase electronic food vouchers & & $1,000,000.00$ \\
\hline 03 Apr 20 & 1,071 & Purchase electronic food vouchers & & $2,624,012.40$ \\
\hline 06 Apr 20 & 1,083 & City of Turin reserves & $663,000.00$ & \\
\hline 06 Apr 20 & 1,083 & Purchase electronic food vouchers & & $663,000.00$ \\
\hline 22 Apr 20 & 1,265 & Soup kitchen meals & & $60,0000.00$ \\
\hline 05 May 20 & 1,491 & Transfer to Damamar for food baskets & & $800,000.00$ \\
\hline 27 May20 & & Fund for Food Solidarity (donations) & *212,225.08 & \\
\hline 04 Jun 20 & 1,666 & $\begin{array}{l}\text { Web portal to manage food voucher } \\
\text { delivery (EU Funded) }\end{array}$ & $99,201.78$ & $99,201.78$ \\
\hline 15 Jun 20 & & Piedmont Region donation & $* 250,000.00$ & \\
\hline 15 Jun 20 & & Turin Chamber of Commerce donation & $* 200,000.00$ & \\
\hline $08 \mathrm{Jul} 20$ & 2,160 & $\begin{array}{l}\text { Web portal to manage food basket } \\
\text { delivery (EU Funded) }\end{array}$ & $40,326.00$ & $40,326.00$ \\
\hline 09 Jul 20 & 2,182 & $\begin{array}{l}\text { Cooked meals provided by social } \\
\text { services (funded with internal resources) }\end{array}$ & $120,000.00$ & $120,000.00$ \\
\hline $22 \mathrm{Jul} 20$ & 2,363 & $\begin{array}{l}\text { Cooked meals provided by social } \\
\text { services }\end{array}$ & $63,446.00$ & $\begin{array}{r}\text { x } 63,446.00 \\
\text { co } 60,000.00\end{array}$ \\
\hline $\begin{array}{l}\text { Total } \\
\text { Balance ren }\end{array}$ & ning & & $6,272,211.26$ & $\begin{array}{r}5,529,986.18 \\
742,225.08\end{array}$ \\
\hline
\end{tabular}

Note(s): *not already allocated to any specific purpose ready to be spent ofinanced with internal resources or financed using the Funds received according to the OCCPD no. 658
COVID-19 and the emergency food

1465



\section{(a)}


AAAJ 34,6

1466 concentration of shops, but an equal distribution across the territory: $15 \%$ in small shops, $60 \%$ in local supermarkets and only $25 \%$ in larger supermarkets.

By 9 April, Turin had spent the budget allocated to food vouchers, and there were still 7,928 unfulfilled applications. Hence, the list of assumed vulnerable people was much longer than initially thought. On the same day, the city announced that these unlucky applicants could instead apply for a food basket through the web platform. As a result of this plan B strategy by the city and NGOs, 4,000 more families received home-delivered food baskets (Minutes of the City Council of 27 April).

Plan B emerged on day one of the voucher program when the overwhelming numbers of vulnerable people became apparent. That afternoon, the Food Bank, DamamarNGO, and the Bank of Charity Works signed an $\mathrm{MoU}$ to boost the collection and distribution of free and surplus food as food baskets. However, the type of food basket and its quality soon became an issue. In part, this was because the kinds of people requesting food during the pandemic did not necessarily fit the standard mould of people the charities typically helped. Traditionally, food assistance meant providing a high calorie, high protein meal. However:

A family with a baby needs other types of food because usually, a food pack has $1 \mathrm{~kg}$ of rice, $400 \mathrm{gr}$ of beans, and one can of tuna and tomato sauce that can last for one week only. (City Council Minutes, 27 April)

\subsection{Accountability and reporting practices}

Meeting the conditions stipulated by the emergency food directive, the Italian government asked cities to open a new accounting ledger entitled the Urgent food solidarity measure. Accordingly, the cities used the same account to collect other public and private donations to assist with the emergency. By so doing, utterly novel government technologies were implemented, including "techniques of notation, computation and calculation" (Rose and Miller, 1992, p. 183). On 6 April, the City of Turin opened its first "food solidarity" account.

We find evidence of specific accounting for emergency relief by the CPD within their reporting infrastructure. For instance, on 23 May, they asked all municipalities, including Turin, to complete and forward a new multi-table report in Excel to accounting for the funds and how they spent them.

One of the compulsory reports, "Home assistance", required an accounting of the expenses incurred for the food's cost and delivered for the vulnerable (period 31.01.2020-31.05.2020). Another, "Hotel assistance", asked for expenses sustained for the allocation of meals.

Another example is Turin's compliance with L.G.D. No. 986, when the city reported a variation of the financial forecast and budget for 2020/2022 to include other donations received from other public and private institutions (Table 3). Turin accounted for the money using two additional sub-accounts. One was for purchasing food by transferring funds to Damamar NGO. Torino Solidale and the management network used the second account for transactions made in providing emergency food relief.

However, while the accounting and accountability practices over the use of emergency funds appear to be adequate, there was no accountability or counting of Turin's invisible denizens, i.e. its 1,200 illegal immigrants and undeclared workers (Hajer and Ambrosini, 2020). Nor was there any accounting for those who did not receive assistance by Torino Solidale. However, Torino Solidale implemented several operating controls. First, operators tried to discourage any opportunistic behaviours by talking to the applicants by phone or face-to-face meetings. Second, the shared database allowed all the hub managers to perform a real-time check of any other support issued to a family member. Third, a second real-time cross-check with the Registry Office gave immediate warning of any transgression. 
During the first wave of COVID-19, roughly 10,000 families received a monthly food basket. Subsequent interviews were conducted personally by Torino Solidale operators to ensure each family's continued emergency status and, in turn, their entitlement to support. Nearly 1,500 families were declared to be past crisis point (Minutes of the Social Policy Committee of 4 June 2020). The intention was for Torino Solidale to be transformed from an emergency measure to a permanent public policy after the first pandemic wave with monthly support to a vulnerable population (Interview with the Vice Mayor of the City of 18 June 2020).

\section{Discussions and conclusions}

In a scenario characterised by "regulations for times of epidemic ... measures taken in plague towns, and the quarantines enforced ..." (Foucault, 1994, p. 92), our analysis of the response to the epidemic in Turin fills a gap in governmentality studies on crises concerning the intersections between accounting and towns, food shortages and epidemics (Foucault, 2007, p. 63). Prior studies on crises have mostly offered investigations of the macro social, economic and political issues surrounding bushfires (Taylor et al., 2014), floods (Lai et al., 2014) or earthquakes (Sargiacomo et al., 2014; Sargiacomo, 2015). The unveiling in our case study of micro-accounting techniques and technologies deployed at the local government level permits a better understanding of the micro issues related to specific population's segments (see Perkiss and Moerman, 2020, p. 11).

The list of technologies called into action, in this case, was extensive, confirming that "government is the right disposition of things arranged to lead to a convenient end" (Foucault, 1991, p. 93). Indeed, there is no doubt that the classification of space and society is pivotal to governmentality during a pandemic. The government was required to launch new tools and technologies, such as the Torino Solidale network. This apparatus established welldispersed food hubs by expanding an already-existing infrastructure. The government used its relational capital with local actors and designed a map based on the town cartography after identifying its constituents' needs across the territory. Our study complements and extends prior literature by adding novel pieces of evidence in a case where a metropolis is facing a severe pandemic and a population either cannot get to or cannot afford to buy food despite its abundance.

In our case, what emerged is an example of how the government is "a science of endless lists and classifications" (Bowker and Star, 1999, p. 16). During Turin's handling of the emergency food assistance program, list-making was of paramount importance as a government technology for "coordinating activity distributed in time and space" (Bowker and Star, 1999, p. 138). Before the pandemic, there were already numbers and lists of the poor. The city had to extend its previous knowledge by creating purpose-built lists, such as the elderly not yet assisted, the disabled who have difficulties with shopping, the infected who must not be allowed to leave their house, the parents with babies who lost their job, and so on. One of the most challenging tasks was tracking the people who would prefer to be uncounted, such as illegal immigrants and undocumented workers, in any other circumstance. Concerned by legal matters, the presumption was that many would not apply for emergency food. The City helped these citizens by providing cooked meals at immigrant centres where visitors could remain anonymous. However, this issue is broad enough and intriguing enough to warrant further research. Unfortunately, for the time being, these individuals remain invisible.

Expanding the governmentality literature on "social lists", one final amalgamated list of "the vulnerable" emerged for Turin to encompass the myriad human situations alluded to above (Foucault, 1994, p. 92). That list identified people as a heterogenous "distribution of cases in a population circumscribed in time or space" (Foucault, 2007, p. 60). Classifications and lists were thus pivotal during the administration of food assistance. The amounts of
COVID-19 and the emergency food

1467 
AAAJ 34,6 money calculated for food-vouchers linked to the number of people in families seeking assistance became "integral to any working infrastructure". They served "the needs of multiple local, national and international information systems" (Bowker and Star, 1999, p. 16).

Turin also made extensive use of accounting and "techniques of notation, computation and calculation" (Rose and Miller, 1992, p. 183) as government technologies. At the national level, in the aftermath of Italy's declaration of a state of emergency, the CPD's COVID-19 expense ledger and Piedmont's unique accounting system (OCCPD n. 639) represented the first act of the launch of novel accounting technologies of government and the inscription of calculative practices. The national Fund for Food Solidarity program, established in March, was distributed using a formula at the regional level and executed at a micro-territorial level. These new forms of data collection, inscription, accounting, and calculative practices were pivotal in administering food deliveries to a diverse population. Thus, purpose-built specific guidelines and technical notes were distributed to local governments, showing both the way to get public money and the new ledger' urgent food solidarity measure' and portraying the way to use the destined public money. The City of Turin followed the new guidelines and then undertook a range of food assistance solutions, including the supply of food vouchers, foodbaskets, and cooked meals. The procedures used to account for the food distribution resonates with Rose and Miller (1992, p. 183), who stressed that government technologies might also include "the standardisation of systems for training, and the inculcation of new habits" as found in these new measures.

Additionally, "procedures of examination and assessment, the invention of ...presentational forms such as tables" Rose and Miller (1992, p. 183) appeared as well as technologies that involved both reporting and control practices. For example, the novel and purpose-built multi-table compulsory reporting required to document the funding used for food assistance to population did not exist before the pandemic. Further, by triangulating data from the City of Turin web-portal, the government exerted control over public money flows, directing them toward food vouchers and baskets. Importantly, opportunities for control were available both top-down and horizontally. For example, any Food Hub could impose real-time controls on people by ascertaining whether they had already received assistance from another hub. Foucault (2007) defines these as space-time controls on territory and population.

In our case, the classification systems emerged, as did organisational and accounting solutions, which "hold a memory of work that has been done (laboratory, organisational, epidemiological, sociological) and so permit the recommendation of a reasonable due process for future work" as affirmed by Bowker and Star (1999, p. 252). These classification systems illuminate new practices from the Italian experience that may inform how responses to pandemics and other crises could be adopted or adapted in different settings (Parker and Northcott, 2016). More importantly, this case shows how governmentality can govern the wealth, health, and happiness of populations with all its good intentions. However, if that population is invisible, there is no accountability for their wealth, health and happiness. Thus, the concept of governmentality needs to expand to consider both the visible and the invisible to ensure accountability to the entire population. Moreover, governmentality should not only apply to government spending, it should also apply to NGOs.

Through this case study, we find that meticulous attention to something as minor as food distribution to vulnerable population confirms that "managing the population does not mean just managing the collective mass of phenomena or managing them simply at the level of their overall results; managing the population means managing it in depth, in all its fine points and details" (emphasis added) (Foucault, 2007, p. 107). These fine points and details are the most important because these fine points are real people.

In these crises, it is the people that matter because if we exclude someone from a list, there can be dire consequences for them. In Turin, many people under pre-pandemic economic 
conditions chose not to be on lists because of their situations. Many of these are the thousands of illegal immigrants who would also have lost their income and access to food (Hajer and Ambrosini, 2020). Even if they did want to join the list, they are unlikely to have the same access to the Internet or a mobile phone or landline or even apply in person as would others. So, they miss out on being included in new lists and miss out on any potential emergency assistance - then, now and probably into the future.

What we can especially learn from this case is that the accounting tools of governmentality are always incomplete. Sometimes unique situations and crises help us to revise and improve the tools we have. Other times, they demand entirely new tools. We must remember that accounting needs both things to count and a context in which to count them and that some people are unaccounted for by choice. When a new context arises that fundamentally changes those preferences, governments must work harder to fulfil their welfare obligations because accounting for the unaccounted in a pandemic is a matter of life and death.

\section{Notes}

1. A member of the Turin Regional Council commenting on new additions to Turin's vulnerable (25 May, 2020).

2. Milan Urban Food Policy Pact (2015).

3. See art. 2, Statute, City of Turin, 2016.

\section{References}

Baker, C.R. (2014), "Breakdowns of accountability in the face of natural disasters: the case of Hurricane Katrina”, Critical Perspectives on Accounting, Vol. 25 No. 7, pp. 620-632.

Bowker, G.C. and Star, S.L. (1999), Sorting Things Out: Classifications and its Consequences, M.I.T. Press, Cambridge.

Centro Einaudi (2019), Rapporto Giorgio Rota su Torino, Turin, Turin.

Dodd, G. (1856), The Food of London, Longman, Brown, Green and Longmans, London.

Foucault, M. (1991), "Governmentality", in Burchell, G., Gordon, C. and Miller, P. (Eds), The Foucault Effect: Studies in Governmentality, Wheatsheaf, Hemel Hempstead, pp. 87-104.

Foucault, M. (1994), "Space, knowledge and power", in Faubion, J.D. (Ed.), Michel Foucault. Power., Penguin, London, pp. 349-364.

Foucault, M. (1988), “The dangerous individual”, in Kritzman, L.D. (Ed.), Politics, Philosophy, Culture: Interviews and Other Writings of Michel Foucault, 1977-1984, Routledge, New York, pp. $125-151$.

Foucault, M. (2007), Security, Territory and Population: Lectures at the College de France, 1977-78, Palgrave Macmillan, New York, NY.

Grafton, J., Lillis, A.M. and Mahama, H. (2011), "Mixed methods research in accounting", Qualitative Research in Accounting and Management, Vol. 8 No. 1, pp. 5-21.

Hajer, M. and Ambrosini, M. (2020), "Who help irregular migrants? Supporters of irregular migrants in Amsterdam (The Netherlands) and Turin (Italy)", REMHU: Revista Interdisciplinar da Mobilidade Humana, Vol. 28 No. 59, pp. 199-216.

Lai, A., Leoni, G. and Stacchezzini, R. (2014), "The socializing effects of accounting in flood recovery", Critical Perspectives on Accounting, Vol. 25 No. 7, pp. 579-603.

MacRae, R. and Abergel, E. (2012), Health and Sustainability in the Canadian Food System: Advocacy and Opportunity for Civil Society, UBC Press, Vancouver.

Parker, L.D. and Northcott, D. (2016), "Qualitative generalising in accounting research: concepts and strategies”, Accounting, Auditing and Accountability Journal, Vol. 29 No. 6, pp. 1100-1131. 
AAAJ 34,6

Perkiss, S. and Moerman, L. (2020), "Hurricane Katrina: exploring justice and fairness as a sociology of common good(s)", Critical Perspectives on Accounting, Vols 67-68, 102022.

Rahaman, A., Neu, D. and Everett, J. (2010), "Accounting for social-purpose alliances: confronting the HIV/AIDS pandemic in Africa*”, Contemporary Accounting Research, Vol. 27 No. 4, pp. 1093-1129.

Rose, N. and Miller, P. (1992), "Political power beyond the state: problematics of government", The British Journal of Sociology, Vol. 43 No. 2, pp. 173-205.

Sargiacomo, M. (2015), "Earthquakes, exceptional government and extraordinary accounting", Accounting, Organizations and Society, Vol. 42, pp. 67-89.

Sargiacomo, M. and Walker, S.P. (2021), "Disaster governance and hybrid organizations: accounting, performance challenges and evacuee housing”, Accounting, Auditing and Accountability Journal, Vol. ahead-of-print No. ahead-of-print, doi: 10.1108/AAAJ-12-2019-4323.

Sargiacomo, M., Ianni, L. and Everett, J. (2014), "Accounting for suffering: calculative practices in the field of disaster relief”, Critical Perspectives on Accounting, Vol. 25 No. 7, pp. 652-669.

Sargiacomo, M., D'Amico, L. and Di Pietra, R. (Eds) (2016), Accounting and Food: Some Italian Experiences, Routledge.

Sciulli, N. (2018), "Weathering the storm: accountability implications for flood relief and recovery from a local government perspective", Financial Accountability and Management, Vol. 34 No. 1, pp. 30-44.

Servalli, S. (2013), "The interface of power and charity in the government of poor: a case from the Italian context in the sixteenth-seventeenth centuries", Accounting, Auditing and Accountability Journal, Vol. 26 No. 8, pp. 1306-1341.

Taylor, D., Tharapos, M. and Sidaway, S. (2014), "Downward accountability for a natural disaster recovery effort: evidence and issues from Australia's Black Saturday", Critical Perspectives on Accounting, Vol. 25 No. 7, pp. 633-651.

Walker, S.P. (2004), "Expense, social and moral control. Accounting and the administration of the old poor law in England and Wales", Journal of Accounting and Public Policy, Vol. 23 No. 2, pp. 85-127.

Walker, S.P. (2014), "Drought, resettlement and accounting", Critical Perspectives on Accounting, Vol. 25 No. 7, pp. 604-619.

Yu, A. (2021), "Accountability as mourning: accounting for death in the time of COVID-19", Accounting, Organizations and Society, Vol. 90, 101198, doi: 10.1016/j.aos.2020.101198.

\section{Corresponding author}

Massimo Sargiacomo can be contacted at: msargiacomo@unich.it

For instructions on how to order reprints of this article, please visit our website:

www.emeraldgrouppublishing.com/licensing/reprints.htm

Or contact us for further details: permissions@emeraldinsight.com 